Article

\title{
Hydrologic and Water Quality Modeling of the Pebble Mine Project Pit Lake and Downstream Environment after Mine Closure
}

\author{
Ann Maest ${ }^{1, *(D)}$, Robert Prucha ${ }^{2}$ and Cameron Wobus ${ }^{3}$ \\ 1 Buka Environmental, Boulder, CO 80302, USA \\ 2 Integrated Hydro, Fort Collins, CO 80525, USA; prucha@integratedhydro.com \\ 3 Lynker Technologies, Boulder, CO 80301, USA; cwobus@lynkertech.com \\ * Correspondence: aamaest@gmail.com; Tel.: +1-303-324-6948
}

Received: 30 June 2020; Accepted: 11 August 2020; Published: 18 August 2020 updates

\begin{abstract}
The Pebble Project in Alaska is one of the world's largest undeveloped copper deposits. The Environmental Impact Statement (EIS) proposes a 20-year open-pit extraction, sulfide flotation, and deposition of separated pyritic tailings and potentially acid-generating waste rock in the pit at closure. The pit will require perpetual pump and treat management. We conducted geochemical and integrated groundwater-surface water modeling and streamflow mixing calculations to examine alternative conceptual models and future mine abandonment leading to failure of the water management scheme 100 years after mine closure. Using EIS source water chemistry and volumes and assuming a well-mixed pit lake, PHREEQC modeling predicts an acidic ( $\mathrm{pH}$ 3.5) pit lake with elevated copper concentrations $(130 \mathrm{mg} / \mathrm{L})$ under post-closure conditions. The results are similar to water quality in the Berkeley Pit in Montana, USA, another porphyry copper deposit pit lake in rocks with low neutralization potential. Integrated groundwater-surface water modeling using MIKE SHE examined the effects of the failure mode for the proposed 20-year and reasonably foreseeable 78-year expansion. Simulations predict that if pumping fails, the 20-year pit lake will irreversibly overtop within 3 to 4 years and mix with the South Fork Koktuli River, which contains salmon spawning and rearing habitat. The 78-year pit lake overtops more rapidly, within 1 year, and discharges into Upper Talarik Creek. Mixing calculations for the 20-year pit show that this spillover would lead to exceedances of Alaska's copper surface water criteria in the river by a factor of 500-1000 times at 35 miles downstream. The combined modeling efforts show the importance of examining long-term failure modes, especially in areas with high potential impacts to stream ecological services.
\end{abstract}

Keywords: pit lake; geochemical modeling; hydrologic modeling; acid mine drainage; ecological services; post-closure; failure modes; mine water management; perpetual treatment

\section{Introduction}

Characterization and modeling of water-related environmental changes at mine sites involve several earth sciences disciplines, including petrology, mineralogy, groundwater and surface water hydrology/hydrogeology, meteorology, and geochemistry (e.g., [1]). Conceptual hydrogeologic models for mines must include mine-related sources, pathways for movement of mine-influenced water, and potentially affected receptors. The elements of a conceptual site model can change throughout a mine's life. In particular, mine-related sources could expand and even disappear as a mine progresses from construction through operations to closure and post-closure. Physical and biogeochemical processes might be excluded due to a lack of information or investigation. The integration of geologic 
and geochemical information and processes with hydrology will improve conceptual site models, which should be tested, revised, and possibly discarded throughout the mine's life [2].

Pit lake water quality predictions have been conducted for at least three decades with varying degrees of success [3-6]. Pit lakes can take many years to form after mining and dewatering stop, especially in arid climates or sites with low permeability bedrock. When modeling long-term changes in water flows and quality, uncertainties increase. Water quality projections at mines are often based on results from laboratory leach tests called humidity cell tests (HCTs) and larger on-site leach tests $[7,8]$. Correction factors are used to translate the rates from the laboratory to the field to account for different volumes of material, temperature, differing availabilities of surfaces for weathering and water contact, and other factors [9-11]. In climatic zones where evaporation markedly exceeds precipitation, mine pit lakes are often terminal sinks with groundwater flowing perpetually toward the pit after mine closure. In wetter climates, pit lakes can become flow-through features that could adversely affect downgradient groundwater and surface water quality, depending on pit water quality and downgradient hydrogeochemical conditions.

This paper presents an interdisciplinary modeling exercise conducted for the Pebble Project in Alaska, USA, which is the site of one of the largest undeveloped copper deposits in the world. Bristol Bay, Alaska, contains three watersheds that drain the Pebble Project area and is the location of the world's largest wild sockeye salmon resource [12]. This juxtaposition has resulted in ongoing conflict between the mine proponents on the one hand and fishermen, native communities, and environmental groups on the other. Precisely because of the sensitive location of the project and the long-term nature of the mine pit lake, it is imperative to carefully examine "reasonably foreseeable" future outcomes of mine development, as required by the U.S. National Environmental Policy Act [13,14]. The Environmental Impact Statement (EIS) for the Pebble Project examines a 20-year mine scenario in detail and mentions the possibility of a 78-year mine, which is considered reasonably foreseeable but was only evaluated qualitatively in the EIS [15] (Draft EIS, DEIS, and Final EIS, FEIS). (Calculations in this study were based on materials available in the Draft EIS. Minor changes to hydrologic and geochemical inputs for the Final EIS do not appreciably affect the conclusions of this analysis, as discussed in Section 3.2.4.). The location of the project and the outline of the 20-year and 78-year extractions are shown in Figure 1. The current mine plan would extract Pebble West, while the 78-year extraction would include the Pebble East portion of the porphyry copper-gold-molybdenum deposit. In either case, the project proposes open-pit extraction and predicts that a pit lake will form. Because outflow from the pit could affect downgradient groundwater and streams that provide salmon spawning and rearing habitat, perpetual pumping, treatment, and release of treated pit water to streams is proposed in the EIS. Similar water management schemes are proposed or are being actively pursued at several U.S. mines including the Berkeley Pit in Montana, the Red Dog Mine in Alaska, The Donlin Gold Project in Alaska, and two open-pit copper mines in New Mexico-the Chino and Tyrone mines, where the State of New Mexico has decided to not allow pit lakes to form in the first place [16-19].

The main aim of the work is to emphasize the importance of critically examining alternative conceptual models and potential failure scenarios using integrated hydrodynamic and geochemical modeling, and to use the results to examine proposed mine operation and planning assumptions presented in the EIS. We investigate the potential failure of the water management and treatment system, and the unrealistic assumption of perpetual stratification of the pit lake 105 years after mine closure. This timeframe was chosen to compare geochemical modeling results against pit water quality predictions presented in the EIS. We use the hydrologic modeling code MIKE SHE (DHI, Horsholm, Denmark) to simulate integrated groundwater, surface water, recharge, and evapotranspiration processes and mine facility dynamics; we also use the geochemical code PHREEQC (Version 3, U.S. Geological Survey, Denver, CO, USA) to estimate pit water quality during post-closure, using inputs from natural and mining sources, and a simple mixing model to predict potential downstream water quality effects using output from MIKE SHE and PHREEQC. The modeling results predict that under a scenario in which the proposed perpetual pump and treat pit water management 
system fails, the lake will overtop on its southeastern side and decant into the South Fork Koktuli River by overland and shallow groundwater flow. The water quality effects are predicted to adversely affect salmon populations for at least 35 river miles downstream.

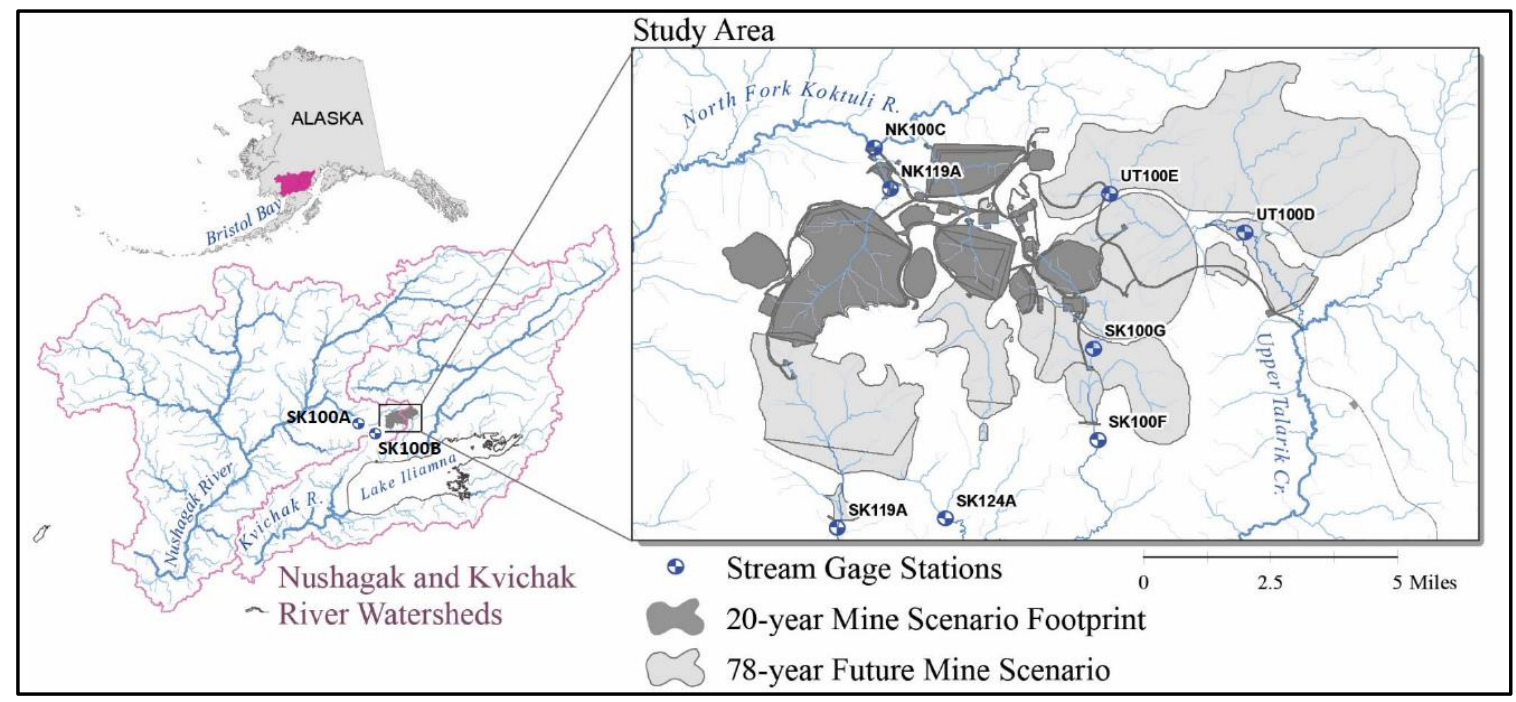

Figure 1. Pebble Project location, outline of the 20- and 78-year mine extents, and existing stream gage locations in the Upper Talarik (UT), South Fork Koktuli (SK), and North Fork Koktuli (NK) watersheds. Source: Map courtesy of David Albert/The Nature Conservancy, modified to add SK 100A and SK 100B stream gage locations.

\section{Materials and Methods}

We combined three modeling approaches to estimate the effects of a water management failure at 105 years post-closure. We used MIKE SHE to simulate hydrologic processes, PHREEQC to simulate pit lake water quality during post-closure, and a simple mixing model to estimate downstream concentrations of key constituents of concern for the Bristol Bay ecosystem.

\subsection{Hydrologic Modeling}

MIKE SHE is an integrated hydrologic code that dynamically simulates coupled groundwater and surface water flow, including recharge, snowmelt, and evapotranspiration (ET) interactions. This dynamic coupling, driven by external spatially distributed hourly air temperature, precipitation, and reference ET, offers distinct advantages over traditional single-process methods (e.g., monthly spreadsheet-based water balance tools, or groundwater modeling tools like MODFLOW (U.S. Geological Survey, Reston, VA, USA). One key advantage is that MIKE SHE simulates more meaningful changes in hydrologic/hydraulic indicators in response to mining land use changes and operations for each storm event, over many years. This is critical for assessing impacts on the surrounding ecosystem, habitat, and environmental flows [20]. In addition, MIKE SHE is able to assess how mining impacts will affect integrated flows and stream temperature [21]. The code was used to simulate several scenarios, including planned water management and abandonment of the 20-year and 78-year managed pits in post-closure. Table S1 lists assumptions and various model inputs specified in MIKE SHE scenario simulations including the pit dimensions, physical and hydraulic properties of the mine components (including waste and water facilities and seepage collection ponds (SCPs)), pumping rates to and from the pit, pit lake levels, and climate sequence date ranges for managed and abandoned 20-year and 78-year scenarios. 


\subsection{Geochemical Modeling, Inputs, and Assumptions}

Geochemical modeling was conducted using the U.S. Geological Survey code PHREEQCI, Version 3.4, with the phreeqc.dat database [22]. The input file is included as Table S2. Species distribution and saturation indices (SI) were examined for each input. The 10 input solutions were mixed in PHREEQC using proportions based on their relative volumes entering the pit during closure. Pit lake water quality was predicted for Closure Year 105 to examine the potential water quality effects related to the MIKE SHE 20-year pit abandonment scenario. Closure year 105 represents a time 55 years after the start of post-closure (Closure Phase 4), at a time consistent with pit lake water quality results from Lorax Environmental [23], who conducted a one-dimensional pit lake water quality model for the EIS, to allow for water quality comparisons. Inputs for geochemical modeling for this study were calculated using source term concentrations and flows for each source entering the pit during the four phases of closure after the end of mining [24]:

- Phase 1: Closure Years 1-15 (open pit backfilling of potentially acid generating (PAG) waste rock and pyritic tailings)

- Phase 2: Closure Years 16-20 (backfilling complete, pit lake filling, no water treatment)

- Phase 3: Closure Years 21-50 (treatment of pit waters; waters from bulk tailings storage facility (TSF), SCPs, treatment plant sludge and reject to pit)

- Phase 4: Closure Years 51-in-perpetuity (maintain pit water levels by pumping, pit water treatment, treatment sludge and reject water to pit).

The following assumptions and sources were used to estimate pit lake water quality during Closure Year 105:

- The pit lake model prepared for the EIS [23] assumes the pit lake will be stratified in perpetuity, with higher solute waters remaining at the bottom of the pit. As noted in Section 3.1.2., many geologic factors render this a highly unrealistic assumption. We assumed the pit lake will be well-mixed, and the removal of pit water to the treatment plant under managed conditions will not change pit water quality. See discussion in Section 3.1. for pit lake mixing. With a stratified pit and pumping to the treatment plant only from the surface (as proposed in [23] but not specifically proposed in the Project Description (Appendix N) of the FEIS), the lower-solute water would be preferentially removed from the pit over time, potentially increasing remaining concentrations when mixing occurs.

- Ongoing releases of metals, sulfate, and acidity from backfilled PAG waste rock and pyritic tailings are not included. Releases from submerged pit walls are also not included.

- To coordinate with source term estimates in the DEIS (next bullet), pit inflows (cfs) are taken from [24] (Appendix A, Tables A2-A5, Average conditions), as shown in Supplementary Table S3. PHREEQC requires volume percentages for mixing calculations (see Section 3.2.).

- Geochemical source terms (pit inflow concentrations) are taken from [25] (Appendix B1 and B2; 50th percentile values) and [24] (Appendix B1 and B2; 50th percentile values) (Table 1). Bulk TSF supernatant and Bulk TSF Main SCP pH values for Closure Phases 2 and 3 were taken from [24] (Table B1.1), because the DEIS [15] (Appendix K4.18) did not include $\mathrm{pH}$ values ("pH was not modeled").

- Assumptions for water quality were the same as those used in [24] (Table B1.2), including that pit wall source terms were used for direct precipitation, additional snow blow, and pit wall runoff.

- Metals will behave conservatively (i.e., no precipitation or adsorption), as assumed in the DEIS $[15,23]$ for chemical failure modes examined (spills of bulk and pyritic tailings and ore concentrate), which assume that the transport of spilled tailings and resulting downstream metal concentrations are only affected by dilution.

- The geologic map of the pit area was used to estimate the proportion of the pit walls that would generate acidic vs. non-acidic leachate. No estimates of the percentage of Pre-Tertiary and Tertiary 
rock on the completed pit walls are provided in the DEIS or associated documents, and the one geologic map of the pit rocks (see Section 3.1.) shows no Pre-Tertiary (non-acidic) material in the open pit area. Lorax Environmental [23] assumed all loadings from Pre-Tertiary wall rock would be acidic, and the water quality model for the FEIS assumed that all PAG wall rock would be $100 \%$ acidic after only 10 years. In this study, the pit walls were assumed to be $90 \%$ Pre-Tertiary acidic and $10 \%$ Tertiary non-acidic material. Lower percentages of Pre-Tertiary material were also modeled to evaluate uncertainty in wall rock leachate inputs.

\subsection{Surface Water Mixing}

Using the PHREEQC modeling projections for pit lake concentrations, we calculated monthly dilution factors for each gage site on the South Fork Koktuli River, based on the ratio of the combined discharge from the abandoned pit outflow and the total streamflow predicted by the MIKE SHE model at each gage site. As a conservative approach, we used pit outflow volumes reached after only two years of pit overtopping; pit outflow volumes increased until a relatively stable long-term outflow was reached after approximately three years of pit discharge. For each constituent, we assumed no attenuation due to precipitation or adsorption in surface water and groundwater. Thus, the metals are modeled as conservative tracers, consistent with the way the constituents are treated in the DEIS (see Section 3.2.1.).

With the exception of lead, the concentrations of all metals in modeled pit lake water quality were more than four orders of magnitude higher than the highest baseline concentrations measured in the South Fork Koktuli watershed (Table 2). Even at gage site SK100A, which is the most downstream location at which we calculated water quality impacts in receiving waters, pit lake outflows generally represent $1 \%$ or more of the total flow in the SFK. The mass loading from the pit lake is therefore more than 100 times higher than the baseline mass load of metals in the SFK drainage. Thus, we ignored the baseline concentrations of each constituent in our dilution calculations. 
Table 1. Water quality source terms and volume percentages used for mixing in PHREEQC.

\begin{tabular}{|c|c|c|c|c|}
\hline Pit Lake Inflow Descriptions & $\begin{array}{l}\text { Water Quality Source Terms } \\
\text { and Assumptions [24] }\end{array}$ & $\begin{array}{l}\text { Solution Number for Mixing } \\
\text { in PHREEQC }\end{array}$ & $\begin{array}{l}\text { Mixing Percentages } \\
\text { Used in PHREEQC }\end{array}$ & $\begin{array}{l}\text { Water Quality Source Terms } \\
\text { Used in PHREEQC }\end{array}$ \\
\hline Direct Precipitation & Pit wall source term & $\begin{array}{l}1 \text { (Pre-Tertiary acidic, } 90 \%) \\
2 \text { (Tertiary non-acidic, } 10 \%)\end{array}$ & $\begin{array}{l}\text { 1: } 17.5 \% \\
2: 1.9 \%\end{array}$ & $\begin{array}{c}\text { Pit wall source term }{ }^{1} \\
\text { (subtracted total evaporation) }\end{array}$ \\
\hline Undisturbed Surface Runoff & SFK 100F & 4 & 4: $8.60 \%$ & SFK $100 \mathrm{~F}^{2}$ \\
\hline Diversion Channel Leakage & SFK 100F & 4 & & SFK 100F \\
\hline Groundwater & Pit area groundwater & 3 & 3: $16.0 \%$ & Pit area groundwater ${ }^{2}$ \\
\hline Additional Snow Blow & Pit wall source term & 1 and 2 & & Pit wall source term ${ }^{1}$ \\
\hline Pyritic Tailings Re-Slurry Water to Open Pit & $\begin{array}{l}\text { Calculated concentrations in } \\
\text { PTSF (assuming full mixing) }\end{array}$ & 5 & 5: $20.1 \%$ & $\begin{array}{c}\text { Open Pit-Closure, Backfilled } \\
\text { Waste Rock, high pyritic tailings }{ }^{3}\end{array}$ \\
\hline Pit Wall Runoff & Pit wall source term & 1 & & Pit wall source term \\
\hline Reject Flows and Sludge Flows from WTP \#2 & $\begin{array}{l}\text { WTPs—sludge and reject } \\
\text { concentrations }\end{array}$ & 6 (sludge) and 7 (reject brine) & $\begin{array}{l}\text { 6: } 2.47 \% \\
7: 0.23 \%\end{array}$ & $\begin{array}{l}\text { WTP sludge and } \\
\text { WTP reject }\end{array}$ \\
\hline Reject Flows and Sludge Flows from WTP \#3 & $\begin{array}{l}\text { WTPs—sludge and reject } \\
\text { concentrations }\end{array}$ & 6 (sludge) and 7 (reject brine) & & $\begin{array}{l}\text { WTP sludge and } \\
\text { WTP reject }\end{array}$ \\
\hline Surplus from Bulk TSF-Phase 2 & Bulk TSF & 8 & $8: 3.2 \%$ & $\begin{array}{l}\text { Bulk TSF, Closure } \\
\text { Phase } 2^{5}\end{array}$ \\
\hline Surplus from Bulk TSF-Phase 3 & Bulk TSF & 9 & 9: $27.9 \%$ & $\begin{array}{c}\text { Bulk TSF, Closure } \\
\text { Phase } 3^{6}\end{array}$ \\
\hline Surplus from Bulk TSF Main SCP & $\begin{array}{l}\text { Calculated concentrations in } \\
\text { Main Embankment SCP }\end{array}$ & 10 & 10: $2.2 \%$ & $\begin{array}{l}\text { Bulk TSF Main Embankment SCP, } \\
\text { Closure Phase } 2^{5}\end{array}$ \\
\hline
\end{tabular}


Table 2. Water quality data, South Fork Koktuli River, Mine Site ${ }^{\text {a }}$.

\begin{tabular}{|c|c|c|}
\hline Analyte & Range & Mean ${ }^{b}$ \\
\hline pH (field, Standard Units) & $3.54-8.85$ & 6.63 \\
\hline Water Temperature $\left({ }^{\circ} \mathrm{C}\right)$ & $-0.33-23.4$ & 4.33 \\
\hline Specific Conductance (field, $\mu \mathrm{S} / \mathrm{cm}$ ) & 20-133 & 52.3 \\
\hline Calcium $(\mathrm{mg} / \mathrm{L}$, dissolved $)$ & $2.28-13.4$ & 6.18 \\
\hline Magnesium (mg/L, dissolved) & $0.35-3.9$ & 1.4 \\
\hline Sodium (mg/L, dissolved) & $1.09-4.67$ & 2.33 \\
\hline Potassium (mg/L, dissolved) & $0.12-1.07$ & 0.36 \\
\hline Alkalinity (total; $\mathrm{mg} / \mathrm{L}$ as $\mathrm{CaCO}_{3}$ ) & $3.1-40$ & 18 \\
\hline Sulfate $(\mathrm{mg} / \mathrm{L})$ & $0.90-28.8$ & 8 \\
\hline Chloride $(\mathrm{mg} / \mathrm{L})$ & $0.14-1.45$ & 0.69 \\
\hline Fluoride $(\mathrm{mg} / \mathrm{L})$ & $0.031-0.23$ & 0.044 \\
\hline Hardness $\left(\mathrm{mg} / \mathrm{L}\right.$ as $\left.\mathrm{CaCO}_{3}\right)$ & $7.91-52.9$ & 20.5 \\
\hline Cadmium ( $\mu \mathrm{g} / \mathrm{L}$, dissolved) & $0.0062-0.074$ & 0.019 \\
\hline Copper $(\mu \mathrm{g} / \mathrm{L}$, dissolved $)$ & $0.15-4.9$ & 1.1 \\
\hline Lead $(\mu \mathrm{g} / \mathrm{L}$, dissolved $)$ & $0.022-0.42$ & 0.072 \\
\hline Zinc ( $\mu \mathrm{g} / \mathrm{L}$, dissolved $)$ & $0.47-11$ & 2.8 \\
\hline
\end{tabular}

a Sample numbers ranged from 326 to $607 ;{ }^{b}$ Using $\frac{1}{2}$ detection limit for values below detection; Source: [15] (Table K3.18-8).

\section{Results}

\subsection{Conceptual Hydrogeologic Model Assumptions and Alternatives}

\subsubsection{Potential Pit Inflows and Outflows}

The pit lake level is proposed to be maintained at $271 \mathrm{~m}$ amsl by pumping and treating in perpetuity to avoid outflow of pit water to the surrounding area. Pumping will allow shallow glacial aquifer groundwater around the pit to continually discharge to the pit [24]. Inflows to the pit from bedrock groundwater during operations are assumed to be minimal because of pit dewatering. The potential for outflow of pit water along faults during operations or closure is not discussed in the EIS.

Figure 2 shows the identified faults in the mine area, and many intersect the pit, especially in the northern and southeastern areas of the pit. The faults could cause an increase in the amount of groundwater entering the pit during operations and could also provide a conduit for the escape of mine-influenced water from the pit during closure/post-closure. In particular, as water levels in the pit rise, the potential for the outward movement of water along faults increases because of the potential for the hydraulic gradient to become directed from the pit to surrounding groundwater. This outward movement of poor-quality water from the Pebble pit could affect both the Upper Talarik and the South Fork Koktuli watersheds. The DEIS assumes that maintaining the pit water level at a control elevation of $271 \mathrm{~m}$ amsl during closure and post-closure will avoid an unplanned discharge through the overburden. However, it says nothing about outflow of mine-influenced water along faults during operations or closure.

At other mine sites, flow along faults has been demonstrated to be a key factor in preventing the containment of mine-influenced waters. Movement of mine-influenced water along faults and outside the capture zone has been shown at the Buckhorn Mine in northern Washington State throughout mine operations and closure [28]. A geophysical study conducted at the Landusky Mine in Montana, USA, showed that mine-influenced water was likely being transported from the open pit along faults to surface water [29]. The conceptual hydrologic model of the Pebble site should include pit water transport along faults and potential water quality impacts to the Upper Talarik and South Fork Koktuli drainages, especially while the pit fills during closure and during post-closure. 


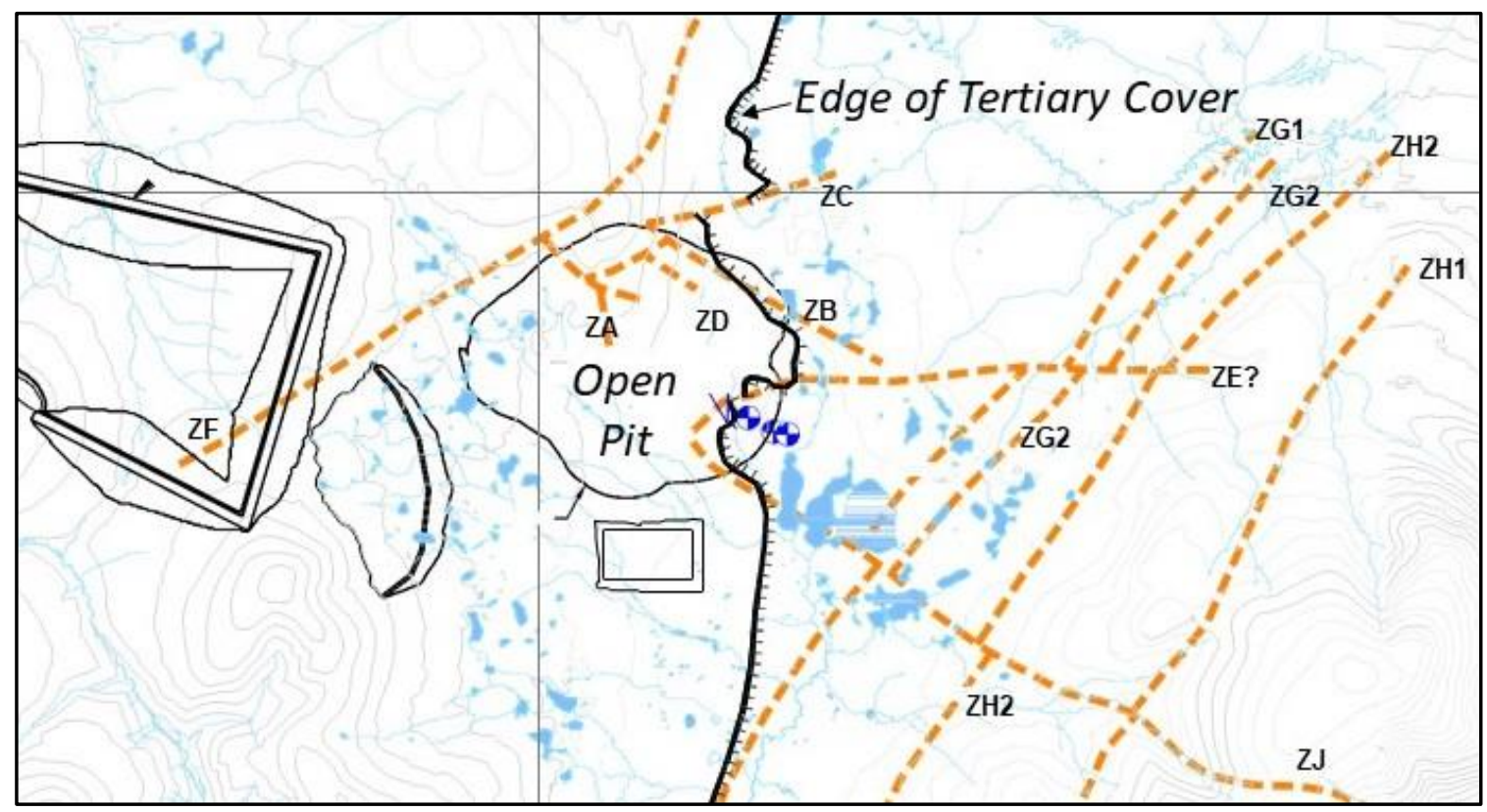

Figure 2. Plan view showing identified and named faults (dashed orange) on and near the mine site, including through the open pit. Black hatched line is the edge of Tertiary cover, showing that only limited sections on the east side of the pit contain Tertiary rocks, and all other areas of the pit contain Pre-Tertiary rocks. Source: Modified from [27] (Figure 2).

\subsubsection{Pit Lake Stratification, Pit Wall Stability, and Water Quality Implications}

Assumptions about pit lake stratification affect pit water quality predictions and estimates of water quality entering the treatment plant during closure and post-closure. If water leaves the pit through faults, from water management failures, or abandonment, assumptions about lake stratification will also affect predictions of downstream and downgradient water quality.

A one-dimensional pit lake model was created for the EIS that assumes the pit lake will remain permanently stratified [23]. This assumption results in metal and other ion concentrations being 20-70 times higher at the bottom of the pit lake relative to the top. The 1-D model runs from Closure Years 16 to 131. The PAG materials from the Pyritic Tailing Storage Facility (PTSF) are backfilled into the pit from Closure Years 1 to 15, and complete mixing of the pit lake is assumed during this time. Lorax Environmental assumes that oxygenated, high-density water treatment plant sludge and brine will be placed in the bottom of the pit during closure, and this will promote stratification and higher dissolved oxygen levels in the bottom waters. However, Knight Piésold [24] (p. 19) does not specify where sludge and reject brine will be "directed" in the pit, and neither does the EIS or its appendices. Water treatment plant sludge and reject water will be highly saline $\left(182,000 \mathrm{mg} / \mathrm{L} \mathrm{SO}_{4}\right.$ for the reject [24]). The discharge of highly saline water to pit surface waters will promote lake mixing. For example, the input of a high-density water treatment plant sludge into the pit lake at the Equity Silver Mine in Canada promoted the complete mixing of the 120-m deep lake [23].

Lorax Environmental [23] provides pit lake water quality data only for the upper $10 \mathrm{~m}$ of the lake, which is assumed to be the well-mixed and lower-solute portion of the lake. The total dissolved solids (TDS) values of pit surface water are predicted to range from 114 to $319 \mathrm{mg} / \mathrm{L}$ from Closure Years 20-125 [23]; surface sulfate concentrations in the same period are predicted to range from 72 to $212 \mathrm{mg} / \mathrm{L}$. In contrast, Knight Piésold [24] (Appendix B2) uses TDS values of 853-1030 mg/L for Closure Phases 3 and 4 (50th percentile values). The discrepancy between these values is not addressed in the EIS. Figures in the Lorax Environmental report show that pit bottom waters are predicted to have values of approximately $6000-7000 \mathrm{mg} / \mathrm{L}$ TDS, $4000-5000 \mathrm{mg} / \mathrm{L}$ sulfate and up to approximately $1.25 \mathrm{mg} / \mathrm{L}$ zinc. If the pit lake turns over, much higher concentrations of solutes will be mixed into the surface waters 
and conveyed to the treatment plant. Contingencies have not been developed to address this potential change in treatment plant inflow water quality.

In addition to the potential for lake overturn due to the input of high-density sludge at the surface, another way the pit lake could turn over is from the sloughing of unstable pit walls into the lake. As shown in Figure 3a, many weak areas exist on the pit walls, and some of these will be above the control elevation of $271 \mathrm{~m}$ amsl. Although methods are recommended for avoiding wall instability problems for areas below the control elevation, such as continued dewatering during early closure, no mitigation measures are proposed for areas above the control elevation during post-closure [15] (Appendix K4.15). Therefore, the potential for landslides exists during closure/post-closure (and even during operations). The FEIS does examine the risk of an in-pit landslide (Figure 3b). Aside from safety concerns, a landslide would severely affect pit water quality by mixing the predicted more contaminated bottom waters throughout the lake. The input of waste rock to the surface of the Brucejack Gold Mine in Canada promoted the mixing of the lake water column [23]. Slope failures at the Sleeper pit lake in Nevada, USA, were acknowledged as a potential source of acidity in the lake, and lime was added to mitigate a turnover or major landslide event [30]. The Sleeper pit lake, which is $110 \mathrm{~m}$ deep, has alternated between being stratified (in summer) and being fully mixed after turnover events (fall and spring) [30]. The modeled backfilled Pebble pit lake would have a length of $2024 \mathrm{~m}$, a maximum depth of $163 \mathrm{~m}$, and a maximum width of $1692 \mathrm{~m}$ [23]. In general, lakes with a high depth-to-width ratio are less likely to turn over; a maximum depth:mean diameter ratio $>25 \%$ has been used to identify lakes that would likely be permanently stratified [16]. As a rough estimate, using the maximum depth, and the average of the maximum width and the length of the proposed Pebble 20 -year pit, this ratio would be $8.8 \%$. As noted by Gammons et al. [30], other factors can also affect whether a pit lake will turnover. Using the $25 \%$ rule of thumb and the fact that the mine plan does not include the addition of less dense water to the lake surface to enhance meromixis, the Pebble pit lake will likely turnover. Most Nevada pit lakes turn over at least once a year, although they might remain meromictic for some years [6]. A major landslide in the Berkeley Pit in Montana, USA, in 1998 raised the lake level by $0.8 \mathrm{~m}$ and induced a probable lake turnover event [16]. If pit wall sloughing occurs in the Pebble pit, the predicted concentrations in Lorax Environmental and Knight Piésold [23,24] would greatly underestimate the concentrations in the water treatment plant influent water, as well as in water that could discharge from the pit along faults and through the upper glacial materials (overburden).

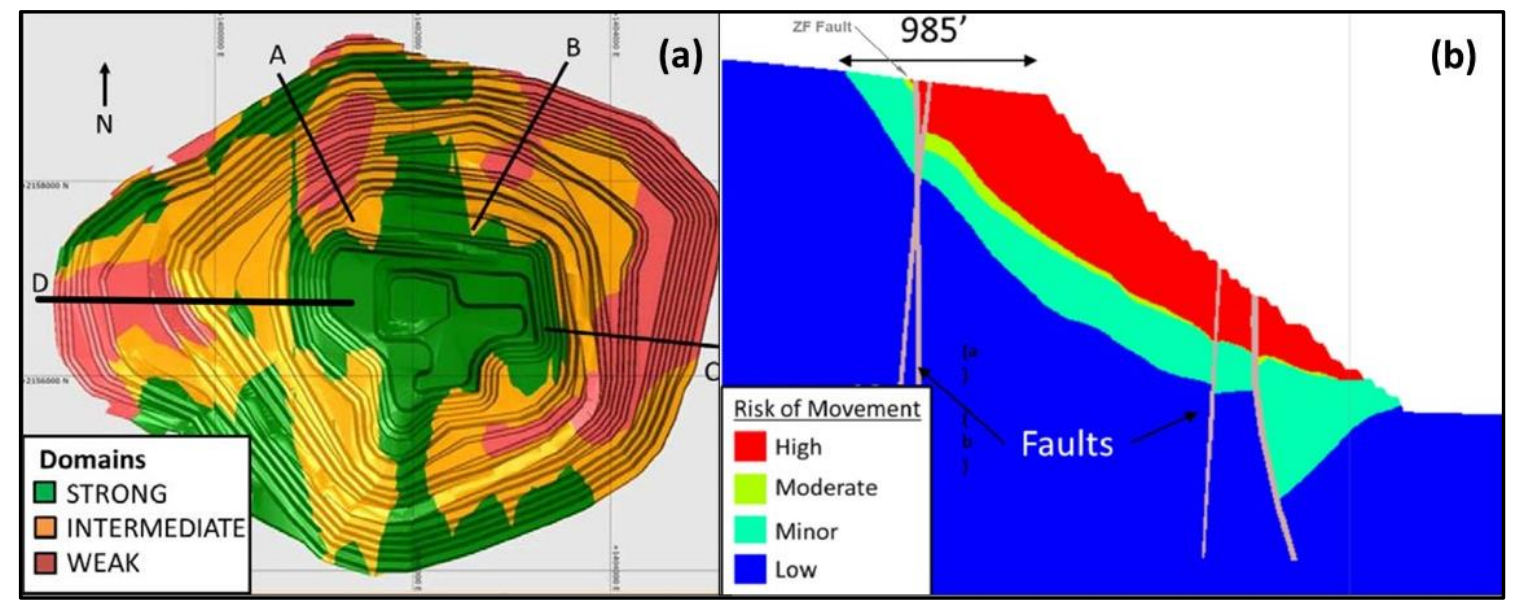

Figure 3. (a) Geotechnical domains in the open pit showing strong, intermediate, and weak rock strength areas. (b) Extent of pit wall failure risks along cross-section A using 25\% weaker rock strength parameters. Sources: [15] (FEIS, Appendix K4.15; (a) Figure K4.15-14; (b) Figure K4.15-18b). 
An alternative conceptual model would include a scenario in which the pit lake turns over, either via an in-pit landslide, earthquakes (shallow crustal and intraslab subduction earthquakes could occur; [15] (FEIS, pp. 4.15-17)), or other means, which would alter the estimated pit lake concentrations and affect the water treatment plant inflow quality.

\subsubsection{Pit Wall Leaching and Pit Water Quality}

Leaching of the pit walls is poorly defined in terms of the proportion that will be Pre-Tertiary vs. Tertiary and will therefore generally produce acidic versus non-acidic leachate. According to the DEIS [15] (Appendix K3.18), the geochemical characterization data are not yet in the block model. The bedrock geology map of the pit area shows no Tertiary rocks in the pit (Figure 4), although another figure shows limited Tertiary rock on the eastern side of the pit (see Figure 2). No cross-sections through the pit have been provided to help determine the geology throughout the depth of the pit. Of the waste extracted from the pit, 80\% would be Pre-Tertiary, which is nearly all PAG [15] (Appendix K3.18), but the proportion remaining in the pit walls and blast zone after the ore has been extracted is not provided.

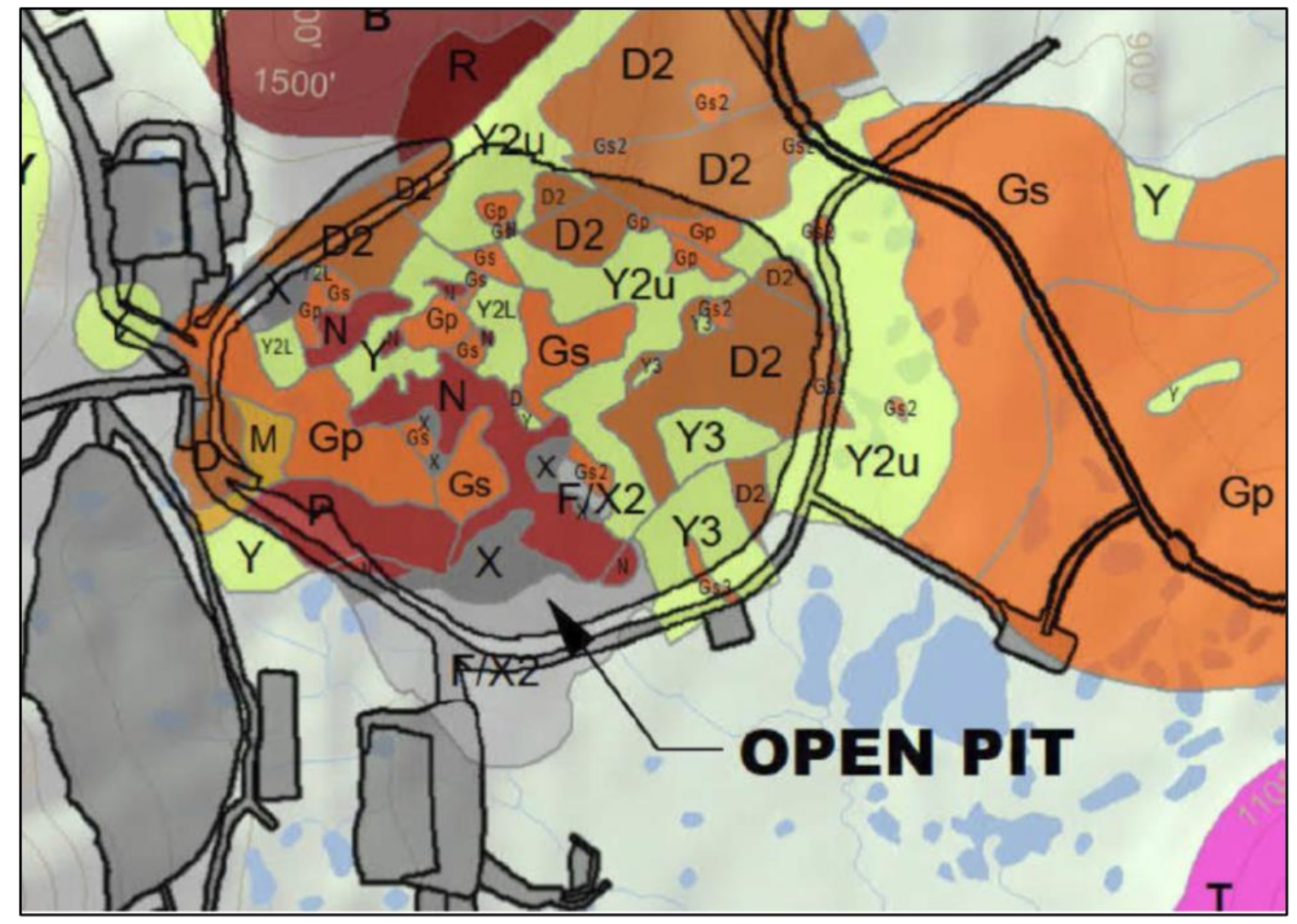

Figure 4. Bedrock geology map of the pit area. All rock units in the pit are Pre-Tertiary units or fault or intrusion breccias. The only Tertiary rocks, shown in magenta with a "T," are located southeast of the pit. Source: [15] (FEIS, Figure 3.13-3).

Hydrothermal alteration can strongly affect environmental behavior and acid-generation potential (AP) by changing the original chemistry and mineralogy of the deposit [1,31]. The only Pre-Tertiary alteration group in the Pebble deposit that has some neutralization potential (NP) is the sodic-potassic (NCK) alteration type [32], which contains some calcite and some dolomite/ankerite. If a commonly used NP:AP ratio of 2 is used to define PAG wastes [33], nearly all the NCK samples would be either PAG or uncertain in terms of their acid-generation potential [32] (Figures 11-3 and 11-4). Of the 29 Pebble East and West Zones Pre-Tertiary samples with mineralogic analyses, 5 had no carbonate, 
14 had trace amounts, 8 had between 1\% and 2\%, one had 5\%, and 1 had 11\% [33] (Appendix 11B). Some of the Pre-Tertiary carbonate is described as ankerite or siderite, which are not effective acid neutralizers [32]. The low carbonate content indicates that the mineralogic NP is low. The NP:AP ratios also indicate that very few Pre-Tertiary samples were non-PAG. Lorax Environmental [23] assumes all Pre-Tertiary pit walls are acidic, but the source terms used in the DEIS for water treatment planning include a term for acidic and non-acidic Pre-Tertiary pit wall leaching [25]. Lorax Environmental [23] predicts that the $\mathrm{pH}$ of the pit lake (upper $10 \mathrm{~m}$ ) during all closure phases will vary between 7.6 and 8.2, and Knight Piésold [24] does not predict pH. A pit lake in a deposit with such a high proportion of PAG ore and waste, and such low NP, is much more likely to be acidic than neutral or alkaline.

Pit lake and source term modeling efforts in the EIS did not take the dissolution of salts from the pit walls and the blast zone into account as pit levels rise. The formation and dissolution of metal-sulfate salts on pit walls will add solutes, including metals and sulfate, to the pit lake, and worsen water quality [6,30]. Newbrough and Gammons [34] conducted a simple experiment by adding water to weathered Berkeley pit wall rock and were able to closely recreate the chemistry of Berkeley pit lake water. Keeping water levels in the pit depressed during operations by dewatering, and at $271 \mathrm{~m}$ amsl throughout closure and post-closure, will keep pit walls exposed to air and water for long periods of time and promote the long-term cyclical formation and dissolution of soluble metal salts [35-37]. These concentrations are best estimated by first-flush HCT values from weathered samples [8], which show that elevated concentrations of sulfate, acidity, copper, and other metals and metalloids can be expected [32] (Appendix 11E). Initial flushes of contaminants were excluded from the "95th percentile concentrations" used to estimate releases from pit walls [25] (p. 12), and this will underestimate concentrations in source terms. Although the source term concentrations used to estimate pit water quality in the EIS are described as 95th percentile values, they are 95th percentile values of the mean HCT values that exclude first flush releases.

A water balance/mixing program (GoldSim) that does not include geochemical reactions used the source term concentrations and flows under different climate scenarios (wet, average, dry conditions) to predict water quality during closure [24]. Such a program cannot calculate $\mathrm{pH}$, and $\mathrm{pH}$ values were not included in their water quality predictions. Concentration caps were applied to the source terms to "constrain the solubility of parameters in the absence of thermodynamic controls when performing geochemical modelling" [25]. The following concentration limits were applied to the predicted bulk and pyritic tailings and pit water quality during closure: sulfate ( $2400 \mathrm{mg} / \mathrm{L})$, aluminum (0.0006 mg/L), copper (0.01 mg/L), iron (0.002 mg/L), and manganese (2 mg/L) [25] (Table 4). The pH was not allowed to drop below 8. In contrast, Pre-Tertiary rock, which would be disposed of in the PTSF and ultimately in the pit and would be present on the walls of the open pit, leached high concentrations of all four metals, sulfate, and acidity in many HCT and field barrel test samples, and had acidic $\mathrm{pH}$ values. For example, copper concentrations in the field barrel tests reached over $10 \mathrm{mg} / \mathrm{L}$ in Pre-Tertiary intrusive and mudstone samples [32] (Appendix 11E and 11I). As a result of the capping, the concentrations of uncapped constituents ( $\mathrm{Sb}, \mathrm{As}, \mathrm{Cd}, \mathrm{Pb}, \mathrm{Co}, \mathrm{Mo}, \mathrm{Ni}, \mathrm{Se}, \mathrm{Sn}, \mathrm{V}$ and $\mathrm{Zn}$ ) were predicted to be higher than $\mathrm{Cu}$ concentrations in the pit lake. Suppressing copper values is especially puzzling for the leaching of a copper ore body, and it limits the predicted concentrations of a contaminant known to be toxic to salmon at low concentrations.

Another important influence on pit water quality is the inflow of groundwater, which accounts for $16 \%$ of pit lake volume at Closure Year 105 (see Section 3.2.2.). The pit area groundwater concentrations used in the EIS are representative of background groundwater quality in the absence of mining. The use of background groundwater quality assumes that the groundwater flowing into the pit during closure will not be affected by blasting or mining activity. The dewatering water and water surrounding a pit that has been blasted for 20 years is contact water rather than unaffected groundwater. Assuming that pit area groundwater will have background concentrations of sulfate, nitrate, and ammonia and will not be affected by blasting and sulfide mineral oxidation does not reflect water quality in mine dewatering wells (see, e.g., [27] for the Buckhorn Mine in Washington, USA). 
All estimates of pit water quality presented in the EIS and associated documents ignore the ongoing leaching of backfilled pyritic tailings and acid-generating waste rock placed in the pit after operations cease. Subaqueous leaching and the oxidation of pyrite by ferric iron has been shown to occur, or is inferred as occurring, in pit lakes $[6,30]$. Submerged column leach tests conducted for the Pebble Project show that once wastes start producing acid, they will continue to release acid, metals, and sulfate even if submerged [32]. Ignoring these releases will underestimate pit lake concentrations, especially in a well-mixed pit lake. Although this is an unrealistic assumption, as a conservative approach we also excluded the leaching of submerged PAG wastes.

\subsubsection{Failure Modes and Abandonment Scenario}

The pit lake is proposed to be pumped and treated in perpetuity and discharged to the South Fork Koktuli and Upper Talarik Creek watersheds [15] (p. 4.17-8; Appendix K4.18, p. K4.18-25). Perpetual pumping and treating would be needed for the proposed project and the 78-year project to avoid the discharge of contaminated pit water into shallow groundwater and nearby streams. Because the pit and remaining SCPs would need to be managed in perpetuity, the probability of a management failure-eventual failure of the pumps and/or failure of the treatment plant-nears $100 \%$. The EIS does not examine failure or abandonment scenarios related to pit lake management, and states that the impacts from the open pit and related mine facilities in total would impact approximately two miles of fish habitat in the upper mainstem South Fork Koktuli River, and one headwater tributary, limited to waters in the footprint of the mine site. We examine an alternative conceptual model that assumes complete pit lake mixing and failure of the 20-year pit lake perpetual pumping and treatment management plan and estimate the downstream water quality effects of the failure. Although insufficient geochemical information was provided in the EIS to evaluate the water quality impacts from a failure of the 78-year pit perpetual water management plan, the MIKE SHE hydrologic modeling results indicate that a failure in the larger mine scenario would have greater impacts, including a faster overflow, higher pit discharge volumes, and impacts to an additional watershed, Upper Talarik Creek.

\subsection{Fate and Transport of Pit Lake Overflow and Outflow}

\subsubsection{Prediction of Pit Lake Abandonment and Effects on Water Flows}

For the abandoned 20-year pit scenario, the results showed that after the pumps cease operating, simulated pit lake levels rise above the southeastern perimeter of the pit and drain overland into the South Fork Koktuli River (Figure 5) at an average annual rate of approximately $2.4 \mathrm{cfs}$. In addition, approximately $0.7 \mathrm{cfs}$ of pit water flows out of the pit through the shallow glacial aquifer and reaches the South Fork Koktuli River (Table 3). The maximum overflow for the 20-year abandoned scenario is predicted to reach approximately $13 \mathrm{cfs}$ during the spring freshet (Figure 6). The possibility of overtopping of the pit from a water management failure was not evaluated in the EIS. MIKE SHE modeling predicts it will take 3-4 years for the 20-year pit to overtop, and $<1$ year for the 78-year pit to overtop. Importantly, once overtopping begins in either scenario, it creates a permanent pit outflow condition.

Similarly, abandonment of the 78-year pit managed scenario causes pit lake levels to overtop the northeastern edge of the pit during post-closure, and flow into the Upper Talarik Creek drainage at an average annual rate of approximately $40 \mathrm{cfs}$, which includes overland and shallow groundwater outflow (see Table 3). Maximum overflow for the 78-year abandoned scenario is predicted to generally occur in the fall and reach approximately 65 cfs (Figure 7). The overflow and outflow of the 78-year pit was not examined in the EIS, which only includes a brief qualitative description of potential impacts from the 78-year mine. The overflow of the larger mine scenario would have a significant impact on the flow and water quality in the Upper Talarik Creek drainage. Although not evaluated, pit discharge via shallow, higher permeability material and overland sheet flow that would overtop the edge of the 
pit will cause erosion at the pit edge, where velocities would increase. This in turn would increase sediment loading to downstream locations.

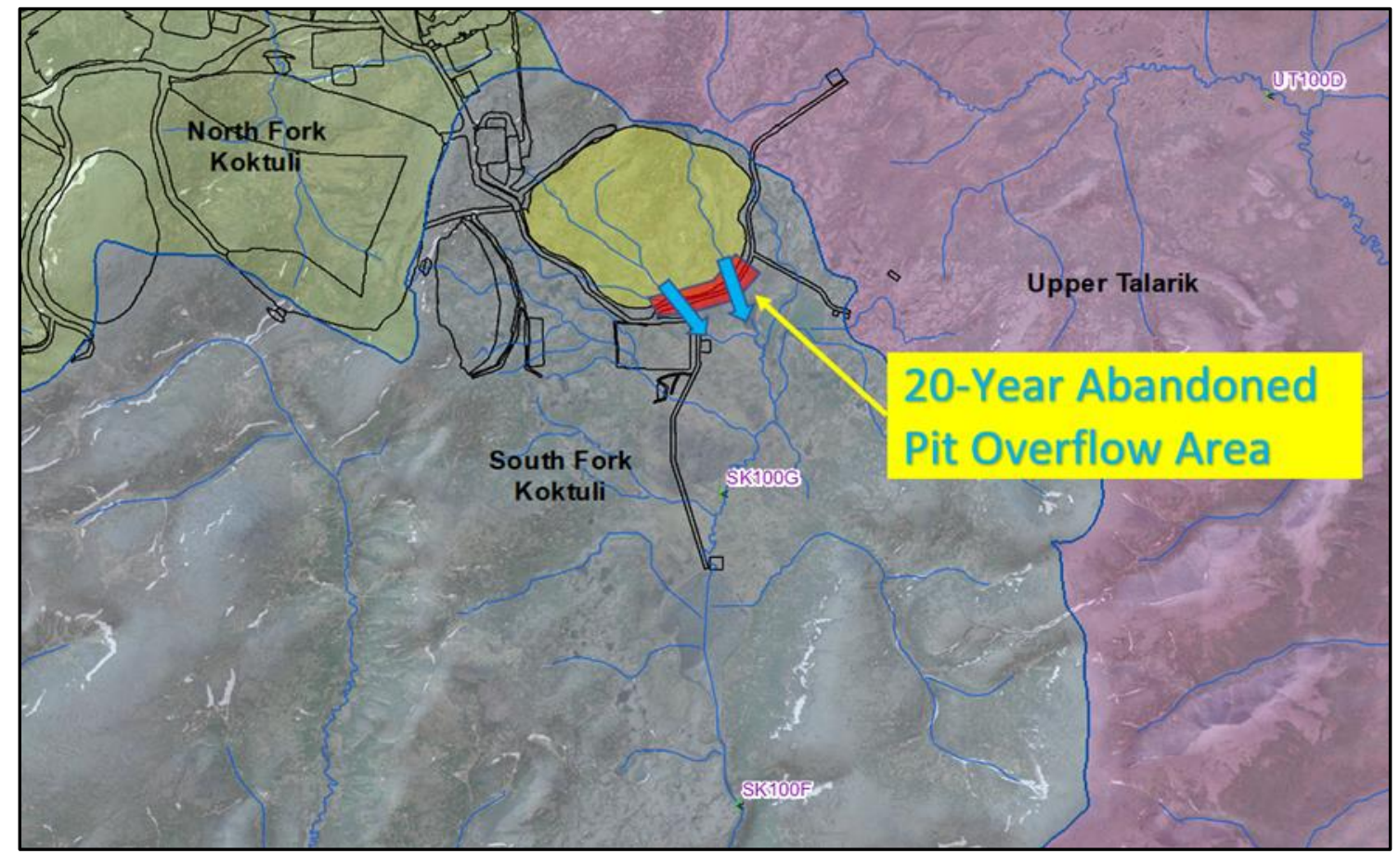

Figure 5. Map showing the location of pit lake overland flow to the South Fork Koktuli watershed headwaters in the 20-year abandoned scenario. An annual average of $3.1 \mathrm{cfs}$ ( $2.4 \mathrm{cfs}$ in surface water and $0.7 \mathrm{cfs}$ in groundwater) is predicted to flow out of the pit and impact water quality in the South Fork Koktuli River.

Table 3. MIKE SHE-simulated average annual pit lake inflows and outflows (cfs) for the 20-year and 78 -year managed and abandoned scenarios. Inflows to the pit are negative and outflows are positive in MIKE She output.

\begin{tabular}{ccccc}
\hline \multirow{2}{*}{ Flow Component } & \multicolumn{2}{c}{ 20-Year Pit } & \multicolumn{2}{c}{ 78-Year Pit } \\
& Managed & Abandoned & Managed & Abandoned \\
\hline GW outflow & 0.0 & 0.7 & 0.0 & 3.4 \\
GW inflow & -2.4 & -1.3 & -35.6 & -39.6 \\
SW outflow ${ }^{1}$ & 0.0 & 2.4 & 118 & 36.0 \\
SW inflow & -0.3 & -0.4 & -1.6 & -1.7 \\
Precipitation & -1.6 & -1.6 & -7.6 & -8.1 \\
AET & 1.2 & 1.2 & 9.8 & 10.5 \\
\hline
\end{tabular}

GW, groundwater; SW, overland flow for outflow and runoff for inflow; AET, actual evapotranspiration. ${ }^{1}$ For the managed 78-year pit scenario, outflow represents average treated discharge to the South Fork Koktuli, North Fork Koktuli, and Upper Talarik drainages to maintain pit lake level at $238 \mathrm{~m}$ amsl and a constant inward gradient to the pit. The managed 78-year scenario includes inflow from 6 seepage collection ponds (SCPs), which add up to $\sim 80 \mathrm{cfs}$. In the abandoned 78-year case, all SCP levels overtop their spillways and discharge to downstream drainages. 


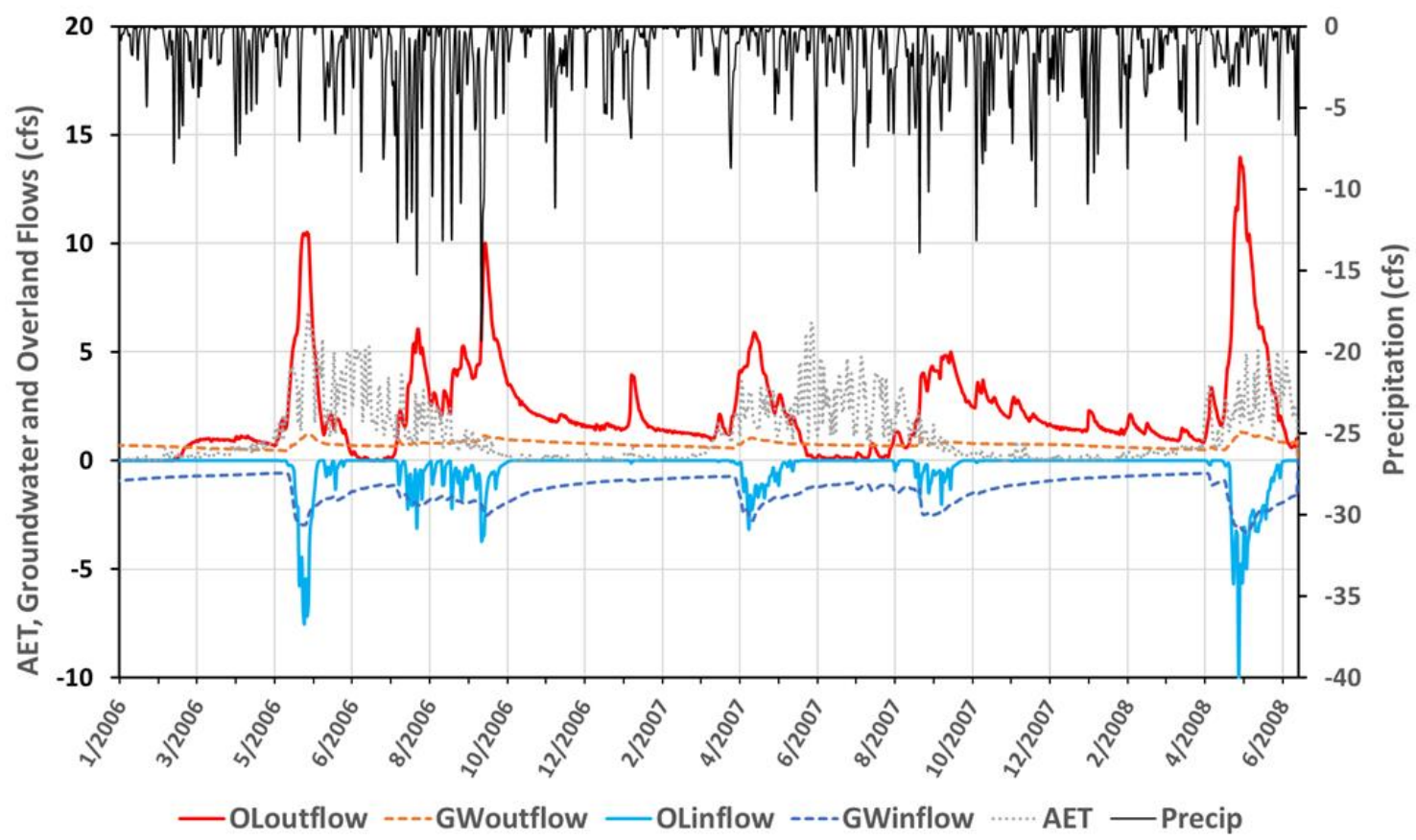

Figure 6. MIKE SHE-simulated pit lake inflows and outflows for the 20-year abandoned pit scenario. Pit lake overland overflow, shown in red (OLoutflow), peaks during the spring freshet to a maximum of approximately $13 \mathrm{cfs}$, delivering pit lake water directly into the South Fork Koktuli River (SFK). In addition, approximately $0.7 \mathrm{cfs}$ discharges via shallow aquifer groundwater flow to the SFK (GWoutflow). Outflows have positive values, and inflows have negative values in MIKE SHE output. Hourly weather data from the dates shown were used to predict post-closure conditions.

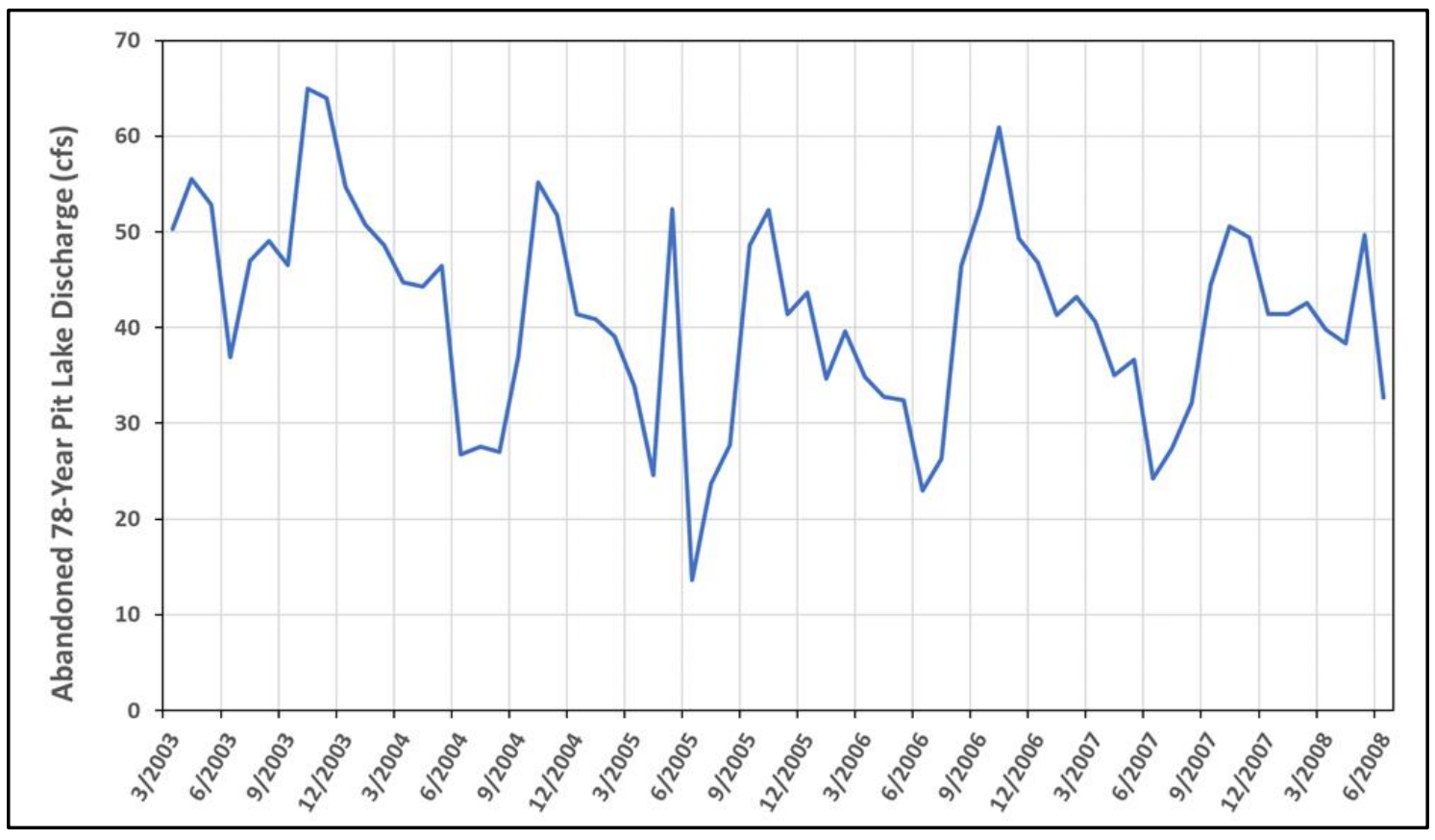

Figure 7. MIKE-SHE-imulated pit lake surface (overland) outflow to Upper Talarik Creek for the 78-year abandoned pit scenario. Pit lake overflow averages approximately $40 \mathrm{cfs}$ and peaks at approximately $65 \mathrm{cfs}$, delivering pit lake water directly into Upper Talarik Creek drainage. Hourly weather data from the dates shown were used to predict post-closure conditions. 


\subsubsection{Prediction of Pit Lake Water Quality Using DEIS Inputs and PHREEQC Modeling}

The input water quality used for the 10 source terms shown in Table 1 is defined in Supplemental Table S2, which provides the input file for the PHREEQC speciation and mixing calculations. Source term concentrations and $\mathrm{pH}$ values were taken directly from the DEIS [24] (Tables B1.1 and B1.3); the treatment plant sludge and reject water quality data did not include $\mathrm{pH}$ values, and a value of 7 was used. Most source term water qualities charge-balanced within $\pm 20 \%$ in PHREEQC, but the PTSF solution did not. We charge-balanced the PTSF solution on sulfate, which resulted in a somewhat higher $\mathrm{pH}$ value and lower sulfate concentrations for this source term.

The modeling was hampered by the lack of information on redox equilibrium (Fe(II) and Fe(III) measurements were not available for any inputs or any water quality or HCT samples), charge-balance issues (for the PTSF solution), and high concentrations of some constituents that produced excessively high SI values. The most problematic input in terms of SI values was the treatment plant reject (Solution 7), which has gypsum and barite SI values of 1.95 and 3.14, respectively, indicating that the estimated calcium, barium, and/or sulfate concentrations are too high. It could be that some of the values were total concentrations in a sludge rather than dissolved values. However, this solution only accounts for $0.23 \%$ of the pit lake mixed solution.

The modeled Pebble pit lake water quality results for key constituents, including $\mathrm{pH}$, sulfate and metals, are presented in Table 4. In addition to being unlikely because the $\mathrm{pH}$ is slightly basic for a pit lake in a PAG deposit, the results in Lorax Environmental [23] are not realistic from a geochemical perspective (assuming concentrations are for dissolved metals) because the dissolved iron and aluminum concentrations should be well below $1 \mathrm{mg} / \mathrm{L}$ for a solution with a $\mathrm{pH}$ of 8.1. In addition, no alkalinity was included in the Lorax Environmental [23] pit lake water quality results, and some alkalinity would be expected at the neutral/slightly basic $\mathrm{pH}$ values predicted.

The comparison with results from Lorax Environmental [23] (Table 3, Closure Year 105) in Table 4 shows that for the PHREEQC modeling results the $\mathrm{pH}$ is acidic (3.54) rather than slightly basic (8.10). The sulfate concentrations are higher, by a factor of nearly 20, and metal concentrations are many times higher. The results are more consistent with a pit lake developed in a PAG ore body, such as the Pebble deposit, with little neutralization potential.

Not all pit lakes developed in porphyry copper deposits are acidic [13,38]. For example, the Yerington Mine pit lake in Nevada, USA, had a pH of 8.45 in 1991, and the Kimbley Pit lake in the Robinson District in Nevada, USA, had a pH of 7.61 in 1993 [38]. The pH of pit lakes can vary considerably, depending on the type of alteration and mineralogy in pit walls and the surrounding rock [39]. However, the low NP of the Pre-Tertiary Pebble rock that comprises the pit walls strongly suggests that acidic conditions would prevail. Although the $\mathrm{pH}$ is higher and metal concentrations are lower, the modeled results are similar to those for the Berkeley Pit in Montana, USA, which is another porphyry copper deposit known to produce acid drainage and that will also require perpetual pumping and treatment.

3.2.3. Prediction of Water Quality Effects to the South Fork Koktuli River from Management Failure or Abandonment

We combined the pit lake concentrations predicted by the PHREEQC model with the projected monthly flow projections from the MIKE SHE hydrologic model in order to estimate downstream concentrations of cadmium, copper, lead, and zinc in the event of an unmanaged pit lake outflow, as summarized in Section 2.3. MIKE SHE model results for the South Fork Koktuli River were available only as far as the junction with the North Fork Koktuli River, at gage site SK100A (see Figure 1). Accordingly, we provide water quality projections only as far as this gage site, which is approximately 35 miles downstream from the 20-year pit. As demonstrated below, however, the water quality projections at gage SK100A indicate that the downstream impacts due to overflows from an abandoned 20-year pit would extend well beyond this distance. 
Table 4. Comparison of Lorax Environmental and PHREEQC-predicted (this study) Pebble pit lake chemistry with Pebble Project water quality criteria, and measured Berkeley Pit water quality.

\begin{tabular}{|c|c|c|c|c|c|c|}
\hline $\begin{array}{l}\text { Parameter } \\
\text { (mg/L or SU) }\end{array}$ & $\begin{array}{c}\text { Lorax } \\
\text { Environmental } \\
\text { (2018), Closure } \\
\text { Year } 105^{\mathrm{a}}\end{array}$ & $\begin{array}{l}\text { PHREEQC } \\
\text { Predicted Pit } \\
\text { Lake, Closure } \\
\text { Year } 105^{b}\end{array}$ & $\begin{array}{c}\text { SFK } \\
\text { WQC } \\
(\mathrm{mg} / \mathrm{L})^{\mathrm{c}}\end{array}$ & $\begin{array}{c}\text { Lorax: } \\
\text { Conc/WQC }\end{array}$ & $\begin{array}{l}\text { PHREEQC: } \\
\text { Conc/WQC }\end{array}$ & $\begin{array}{c}\text { Berkeley Pit, } \\
\text { MT, USA } \\
\text { 10/16/87 d }\end{array}$ \\
\hline $\mathrm{pH}$ & 8.10 & 3.54 & $6.5-8.5$ & NA & NA & 2.8 \\
\hline $\mathrm{Al}$ & 1.0 & 155 & 0.087 & 11.5 & 1780 & - \\
\hline B & 0.034 & 0.06 & 0.75 & 0.0 & 0.08 & - \\
\hline $\mathrm{Ba}$ & 0.015 & 0.04 & 2 & 0.0 & 0.02 & - \\
\hline $\mathrm{Ca}$ & 59 & 308 & - & NA & NA & 462 \\
\hline $\mathrm{Cd}$ & 0.0017 & 0.231 & 0.00008 & 21.3 & 2890 & 1.3 \\
\hline $\mathrm{Cu}$ & 0.27 & 130 & 0.00219 & 123 & 56,200 & 156 \\
\hline $\mathrm{Fe}$ & 1.7 & 395 & 1 & 1.7 & 382 & 386 \\
\hline $\mathrm{Mn}$ & 0.89 & 14.1 & 0.05 & 17.8 & 282 & 95 \\
\hline $\mathrm{Pb}$ & 0.0038 & 0.020 & 0.00039 & 9.7 & 51.3 & - \\
\hline $\mathrm{SO}_{4}$ & 173 & 3140 & 250 & 0.7 & 12.6 & 5740 \\
\hline $\mathrm{Zn}$ & 0.18 & 34.8 & 0.02895 & 6.2 & 1200 & 280 \\
\hline
\end{tabular}

a [23] (Table 3); ${ }^{\mathrm{b}}$ PHREEQC prediction using Knight Piésold [24] flows into pit; charge balance on sulfate for PTSF (Solution 5). Assumes full mixing of pit lake; ${ }^{\mathrm{C}}$ [15] (DEIS, Appendix K3.18, Table K3.18-1); Cd, Cu, Pb, Zn are hardness-based, total concentrations; Fe is for total concentrations; ${ }^{\mathrm{d}}$ [38] (Table 1). WQC, water quality criteria.

Figure 8 shows the projected exceedance factors for cadmium, copper, lead, and zinc at gage sites SK100F, SK100B and SK100A, at river distances of approximately 3.5, 20, and 35 miles downstream from the pit, respectively. In each graph, concentrations are shown as exceedance factors relative to applicable water quality criteria and are shown for each month of the year. For comparison, Figure 8 (lower right graph) shows the exceedance factors at site SK100A if the pit lake concentrations calculated as part of the EIS [23] were correct. The individual criteria do not consider multiple metal toxicity.
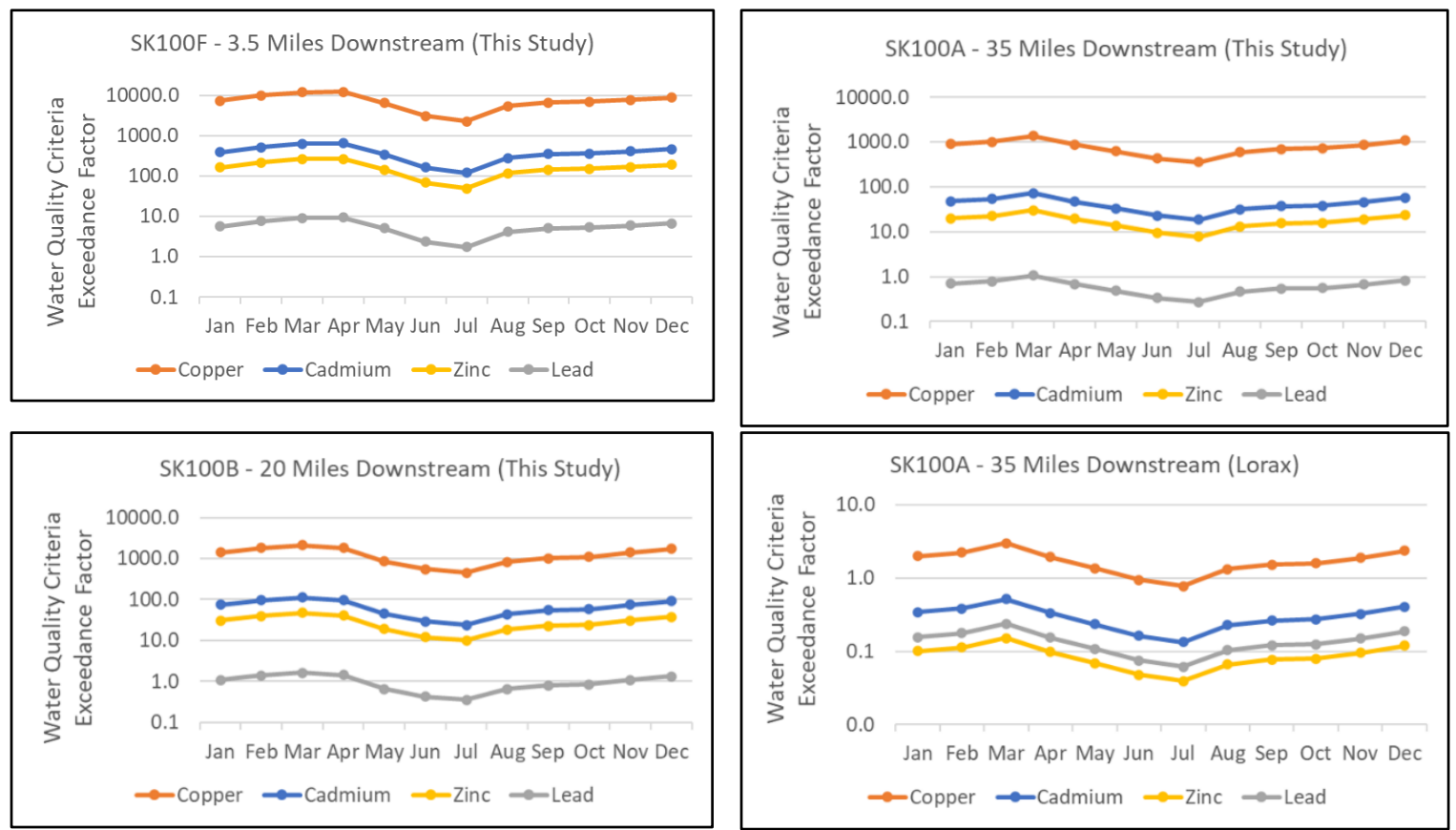

Figure 8. Results for water quality criteria exceedance factors at gaging stations in the South Fork Koktuli River for this study and for the Lorax Environmental [23] study. Note the log scale on the $y$-axis. At an exceedance factor of 1.0, the predicted stream concentration equals the water quality criterion. 
As shown in Figure 8, the concentrations of all metals modeled for this study are projected to exceed hardness-based water quality criteria for at least some gage sites, and in many cases water quality criteria are exceeded by many orders of magnitude. Copper and cadmium concentrations are predicted to be the highest relative to water quality criteria. Copper concentrations are projected to remain approximately 1000 times higher than the hardness-based water quality criterion 35 miles downstream from the pit, and cadmium concentrations are predicted to exceed the hardness-based criterion by a factor of nearly 100. Due to differing ratios of pit overflow rates and instream flow rates in the South Fork Koktuli River throughout the year, each of the constituents shows monthly variability.

Although the predicted values for the upper, more dilute portion of the simulated stratified pit lake from Lorax Environmental [23] in Table 4 are substantially lower, mixing calculations show that if a pit lake with that predicted water quality were to overflow into the South Fork Koktuli River, the copper concentrations at SK100A (35 miles downstream) would still exceed water quality criteria for all months except June and July (see Figure 8, lower right graph). Cadmium concentrations would also exceed water quality criteria at a distance of 20 miles downstream from the pit for half the year using predictions from Lorax Environmental.

Although insufficient information is provided in the EIS to conduct a similar exercise for overflows from the 78-year abandoned pit, the much higher outflows (see Table 3 and Figure 7) ensure that impacts would adversely affect Upper Talarik Creek to a greater extent, even though it has somewhat higher hardness and alkalinity than the upper South Fork Koktuli River. This study examines the effects of pit lake overflow and outflow on the chemistry of the South Fork Koktuli River. The physical effects of the proposed mine, both the 20-year and the 78-year scenarios, would also result in the loss of miles of salmon streams and tributaries, and thousands of acres of wetlands that are contiguous with salmon streams or tributaries [40].

\subsubsection{Discussion of Uncertainty}

Forward hydrogeochemical modeling always has high uncertainty, and by definition cannot be calibrated to conditions in the timeframe modeled because it is years into the future [41,42]. The purpose of this exercise is to test an alternative conceptual model (pit lake mixing) and a failure mode (failure of pit lake pumps and treatment system, followed by outflow of pit water) that is likely to occur in the future with mine abandonment, but that was not considered in the EIS. The planned perpetual pumping and treatment of the pit lake is designed to avoid the outflow of pit water from the lake, but the potential failure of this water management scenario would cause the release of mine-influenced water to groundwater and streams.

The adsorption of metals on glacial materials as outflow moves through groundwater was not considered, and the precipitation of and adsorption onto solids in the South Fork Koktuli River was also not evaluated. This approach is consistent with that taken in the EIS to evaluate tailings and ore concentrate spills entering area rivers. More than three times as much overland flow is predicted to enter the river as groundwater flow (the ratio of overland flow to groundwater outflow during abandonment is 3.4; see Table 3), and adsorption in the overland flow component would be less than adsorption in the groundwater outflow component. The alkalinity of the SFK is very low (see Table 2), and precipitation of carbonates is not expected, but metal hydroxides could precipitate as the pit outflow reaches the stream and reduce the predicted magnitude of exceedances downstream. However, the high volume of outflow entering the stream relative to the baseflow in the stream, as shown in Figure 9 for certain times of the year, and the low background alkalinity suggest that pit outflow would overwhelm the chemistry of the stream. This would be especially true during the rising limb of the hydrograph in the spring (usually in March or April), when pit lake outflow during abandonment would exceed stream baseflow conditions in the uppermost reaches of the South Fork Koktuli drainage. The exceedance values shown in Figure 8 are highest in these months, and this is when the adverse effects to salmon would be most pronounced downstream. 


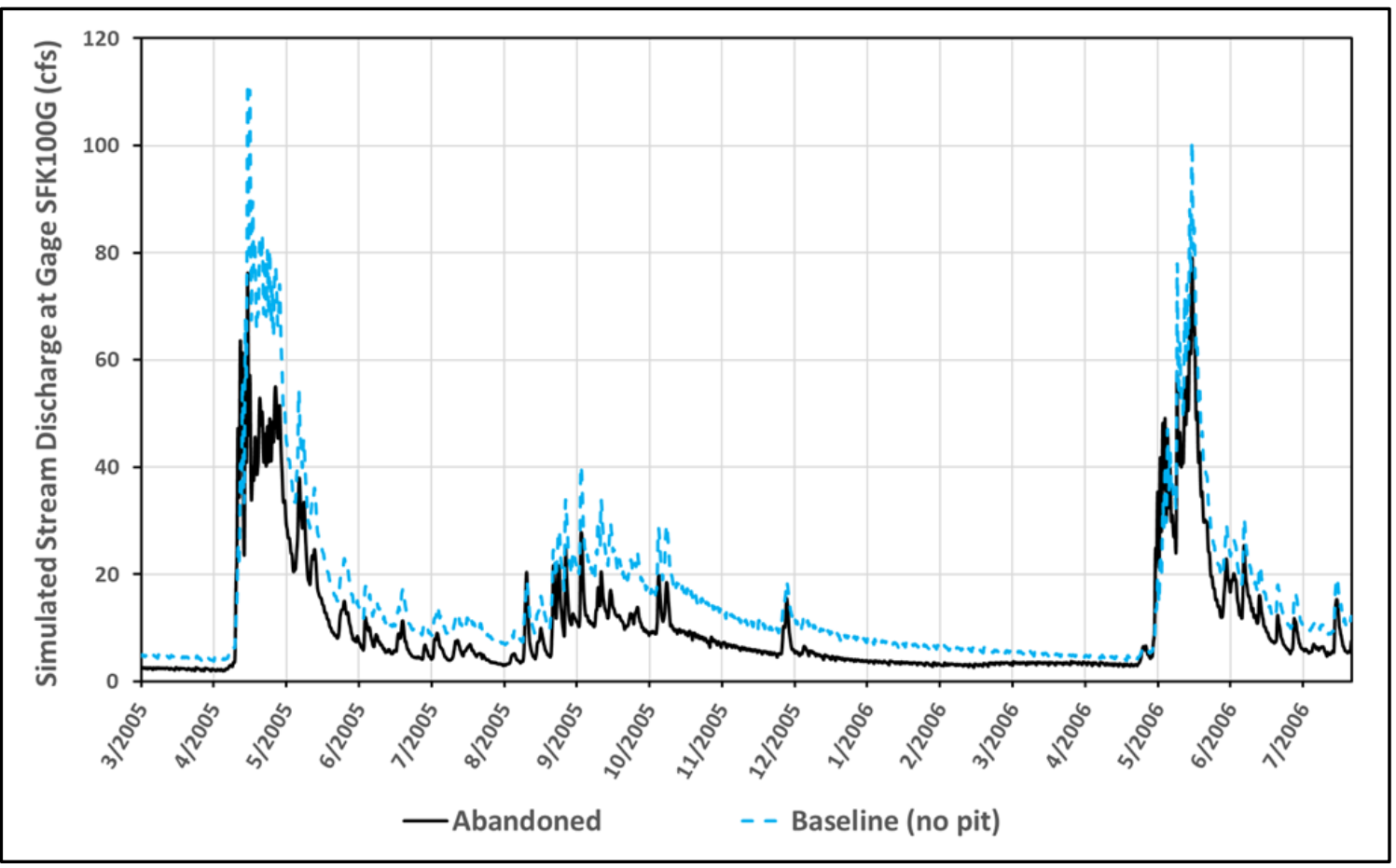

Figure 9. Simulated stream discharge at gage SK100G (cfs) in the upper South Fork Koktuli River (see Figure 1) for baseline (no pit) and abandoned conditions. Hourly weather data from the dates shown were used to predict post-closure conditions.

In many respects, this is an overly conservative evaluation because it does not include the dissolution of secondary minerals from several likely sources, including more than 200 million tons of PAG waste that are planned to be deposited in the pit upon closure [15] (FEIS, Appendix N). Further, the values used for the source terms ignore first-flush concentrations, which are known to recur seasonally. As pit levels rise with the failure of the pumping system, metal-rich salts on the pit walls and in the blast zone around the walls would dissolve in the rising waters-these inputs are also not included. Leaching of wall rock and PAG backfill below the pit lake level was also not included. The additive effects of multiple metals on fish toxicity in the South Fork Koktuli River were also not considered.

In addition, using baseline groundwater quality for groundwater inflows to the pit will likely underestimate the concentrations of certain constituents (nitrate, sulfate, potentially metals) in groundwater moving through the blast zone around the pit, which will be affected by the use of ANFO (ammonium nitrate-fuel oil) for blasting, and the dissolution of metal sulfate salts from the oxidation of sulfide minerals in the mineralized rock surrounding the pit. The nitrate concentrations would be expected to decrease after blasting stops, but the sulfate and metal concentrations would not and could potentially increase over time, especially for groundwater entering through the upper portions of the pit that were dewatered by mine pumping.

Geochemical modeling results (PHREEQC) contain large exceedances of SI values for some phases (barite, gypsum), suggesting that the calcium, barium and/or sulfate concentrations estimated in the EIS are too high. The source term with the highest SI values for those phases is the treatment plant reject water (SI values for gypsum and barite were 1.95 and 3.14, respectively). As a treatment brine, this term also had a high ionic strength $(3.05 \mathrm{~mol} / \mathrm{kg})$. Uncertainty in treatment plant sludge reject concentrations and the proportion that is dissolved vs. solid is the most likely source of this error. However, the treatment plant reject input is only $0.23 \%$ of the total pit inputs, and errors in this source would not greatly affect pit water quality predictions. 
Uncertainties in the proportion of Pre-Tertiary acidic vs. Tertiary non-acidic wall rock will induce errors in the geochemical modeling results. Based on the available geologic map (see Figure 4), and assuming even more Tertiary wall rock than indicated, the ratio used in the simulation was $90 \%$ acidic, 10\% non-acidic. Varying the ratio in steps down to 70:30 in PHREEQC input produced little change in $\mathrm{pH}$ (increased from 3.54 to 3.56) or copper concentrations (decreased by $0.1 \mathrm{mg} / \mathrm{L}$ ).

The pit lake inflow values (cfs) changed between the DEIS and the FEIS [43] (Appendix B1, Tables B1.2-B1.5), and a sensitivity analysis conducted for the FEIS included a base case and a high bedrock hydraulic conductivity assumption. Compared to this study, the FEIS base case average annual values for some pit input flows are lower (surface runoff and groundwater, which was lowered from $16.0 \%$ to $7.1 \%$ of total pit inflows), and some are higher (wall rock and PTSF re-slurry water to the pit). We conducted an analysis to evaluate pit inflow changes between the DEIS and the FEIS, and the different percentages for each of the 10 inputs were recalculated and used as inputs for pit lake mixing in PHREEQC. The predicted $\mathrm{pH}$ value was slightly lower using the FEIS input flows (3.49 vs. 3.54 for the DEIS input flows), and copper concentrations were somewhat higher (171 vs. $130 \mathrm{mg} / \mathrm{L}$ for the DEIS input values). The DEIS source term concentrations were used in this analysis, even though the source terms for leached waste rock and high pyritic tailings were assumed to be more acidic in the FEIS [44].

The inclusion of projected climate change effects on precipitation (timing and amounts), evaporation, and temperature would affect hydrologic assumptions and outcomes. Potential future climate change effects were not modeled using MIKE SHE for this study. However, previous work has demonstrated that climate change could substantially affect the hydrology of the Pebble Project area [21]. Despite the inherent uncertainties in the geochemical and hydrologic modeling outputs, the key results are that the constituents, including cadmium and copper, exceed water quality criteria by factors of approximately 50-100 and 500-1000, respectively, 35 miles downstream from the mine site, under the water management failure scenario. Given that the current mine plan is to pump and treat the pit lake water in perpetuity, the probability of such a failure occurring at some point in the future must approach $100 \%$. A pit water management system failure is thus a reasonably foreseeable event and should have been considered in the FEIS.

\section{Conclusions}

We examined the effects of an alternative pit lake conceptual model, which allows mixing, and a reasonably foreseeable water management failure scenario for the Pebble Mine Project in Alaska, USA. We modeled distributed weather inputs, the post-closure hourly dynamics of the pit lake flows and levels, and the surrounding coupled hydrologic system using the fully integrated, physically based code MIKE SHE. We modeled pit water quality using reported flow and concentration values in the DEIS using the geochemical code PHREEQC. Hydrologic modeling results predict that the pit lake overtops and flows southeast into the upper South Fork Koktuli drainage for the currently proposed 20-year project, and overflows into the Upper Talarik drainage for likely expansion to the 78-year mine plan. Mixing calculations under the 20-year failure scenario predict that pit lake overflow adversely affects salmon populations for at least 35 miles downstream in the South Fork Koktuli drainage.

The approach and the conclusions are relevant to other mines considering or currently requiring perpetual pumping and treatment of pit lakes and show the importance of considering alternative conceptual models in mine site design and permitting. Our results also illustrate the advantages of using integrated hydrologic codes for assessing inherently complicated and uncertain future conditions at mine sites. Evaluating reasonably foreseeable failure modes using a multidisciplinary approach improves our fundamental understanding of the cumulative impacts to hydroecological systems.

Supplementary Materials: The following are available online at http://www.mdpi.com/2075-163X/10/8/727/s1, Table S1. Summary of assumptions and model inputs specified in MIKE SHE Scenario Simulations; Table S2. PHREEQC Input File; Table S3. Inflows to Pebble Pit, Closure Phases. 
Author Contributions: Conceptualization, A.M., R.P., and C.W.; methodology, A.M., R.P., and C.W.; software, R.P. (DHI offers 1-mo trial version to assess inputs, results, assumptions, etc.); validation, R.P. (see https: //www.integratedhydro.com/MSHEVerificatio_Final\%20report10_1_WAppendix.pdf); writing-original draft preparation, A.M. and C.W.; writing—review and editing, A.M., C.W., and R.P.; funding acquisition, A.M., C.W., and R.P. All authors have read and agreed to the published version of the manuscript.

Funding: This research was funded by the Wild Salmon Center, Oregon, USA.

Acknowledgments: A.M. wishes to thank Kirk Nordstrom for helpful discussions regarding the geochemical modeling output.

Conflicts of Interest: The authors declare no conflict of interest. The funders had no role in the design of the study; in the collection, analyses, or interpretation of data; in the writing of the manuscript, or in the decision to publish the results.

\section{References}

1. Nordstrom, D.K. Hydrothermal processes governing the origin, transport and fate of major and trace elements from mine wastes and mineralized rock to surface water. Appl. Geochem. 2011, 26, 1777-1791. [CrossRef]

2. Bredehoeft, J. The conceptualization model problem-Surprise. Hydrogeol. J. 2005, 13, 37-46. [CrossRef]

3. Davis, A.; Eary, L.E. Pit lake water quality in the western United States: An analysis of chemogenetic trends. Min. Eng. 1997, 46, 98-102.

4. Kuipers, J.R.; Maest, A.L.; MacHardy, K.A.; Lawson, G. Comparison of Predicted and Actual Water Quality at Hardrock Mines: The Reliability of Predictions in Environmental Impact Statements; Prepared for Earthworks: Washington, DC, USA, 2006; Available online: https://pebbleprojecteis.com/files/81bbe585-36ce-49d3-a782ea43a574f09f (accessed on 28 June 2020).

5. $\quad$ Beddoes, P.; Herrell, M.; Vandenberg, J.; Richards, J.; Millar, R.; McMahen, K. Validation of Springer Pit Lake Water Balance and Water Quality Model, Mount Polley Mine, British Columbia, Canada. In Proceedings of the IMWA 2016, Freiberg, Germany, 11-15 July 2016; pp. 251-260.

6. Newman, C.P.; Cluff, T.; Gray, T.; Beale, G. Aqueous Geochemistry and Limnology of the Sleeper Pit Lake, Nevada, USA: Evidence for Long-Term Subaqueous Solute Generation in Mine Pit Lakes. J. Geosci. Environ. Prot. 2019, 7, 64-81. [CrossRef]

7. Parbhakar-Fox, A.; Lottermoser, B.G. A critical review of acid rock drainage prediction methods and practices. Miner. Eng. 2015, 82, 107-124. [CrossRef]

8. Maest, A.S.; Nordstrom, D.K. A geochemical examination of humidity cell tests. Appl. Geochem. 2017, 81, 109-131. [CrossRef]

9. Banwart, S.A.; Evans, K.A.; Croxford, S. Predicting mineral weathering rates at field scale for mine water risk assessment. Geol. Soc. London Spec. Publ. 2002, 198, 137-157. [CrossRef]

10. Bornhorst, T.J.; Logsdon, M.J. Predicting Future Water-Quality Impacts from Mining: A 52-Year-Old Field Analog for Humidity Cell Testing, Copperwood Deposit, Michigan. Econ. Geol. 2016, 111, 527-542. [CrossRef]

11. Lapakko, K.; Olson, M. Scaling Laboratory Sulfate Release Rates to Operational Waste Rock Piles. In Proceedings of the 10th ICARD/IMWA Annual Meeting, Santiago, Chile, 20-25 April 2015; p. 15.

12. Ruggerone, G.T.; Peterman, R.M.; Dorner, B.; Myers, K.W. Magnitude and Trends in Abundance of Hatchery and Wild Pink Salmon, Chum Salmon, and Sockeye Salmon in the North Pacific Ocean. Mar. Coast. Fish. 2010, 2, 306-328. [CrossRef]

13. Bowell, R.J. The hydrogeochemical dynamics of mine pit lakes. Geol. Soc. London Spec. Publ. 2002, 198,159-185. [CrossRef]

14. U.S. Environmental Protection Agency. Consideration of Cumulative Impacts in EPA Review of NEPA Documents. Office of Federal Activities (2252A). EPA 315-R-99-002/May 1999. Available online: https: //www.epa.gov/sites/production/files/2014-08/documents/cumulative.pdf (accessed on 26 June 2020).

15. U.S. Army Corps of Engineers. 2019; Pebble Project EIS. Draft Environmental Impact Statement. February. https://www.pebbleprojecteis.com/documents/eis; and U.S. Army Corps of Engineers. Pebble Project EIS. Final Environmental Impact Statement; 2020. Available online: https://pebbleprojecteis.com/documents/ finaleis (accessed on 29 June 2020).

16. Gammons, C.H.; Duaime, T.E. Long Term Changes in the Limnology and Geochemistry of the Berkeley Pit Lake, Butte, Montana. Mine Water Environ. 2006, 25, 76-85. [CrossRef] 
17. SENES Consultants Ltd. Assessment of Water Treatment Methods Applicable for Closure, Red Dog Mine, Alaska. Prepared for Teck Cominco Alaska Inc; 2004. Available online: http://dnr.alaska.gov/mlw/mining/ largemine/reddog/publicnotice/pdf/sde4.pdf (accessed on 26 June 2020).

18. U.S. Army Corps of Engineers. Donlin Gold Project. Final Environmental Impact Statement. Chapter 3: Environmental Analysis, 3.6 Groundwater Hydrology; 2018. Available online: https://eplanning.blm.gov/ public_projects/nepa/35860/154866/189534/Sec_3.6_Groundwater_Hydrology.pdf (accessed on 26 June 2020).

19. New Mexico Office of the Natural Resource Trustee. Final Groundwater Restoration Plan for the Chino, Cobre, and Tyrone Mine Facilities. 2012. Available online: https://www.cerc.usgs.gov/orda_docs/DocHandler. ashx?task=get\&ID=1177 (accessed on 25 June 2020).

20. Prucha, R.; Graham, D.; Watson, M.; Avenant, M.; Esterhuyse, S.; Joubert, A.; Kemp, M.; King, J.; Le Roux, P.; Redelinghuys, N.; et al. MIKE-SHE integrated groundwater and surface water model used to simulate scenario hydrology for input to DRIFT-ARID: The Mokolo River case study. Water SA 2016, 42, 384. [CrossRef]

21. Wobus, C.; Prucha, R.; Albert, D.; Woll, C.; Loinaz, M.; Jones, R. Hydrologic Alterations from Climate Change Inform Assessment of Ecological Risk to Pacific Salmon in Bristol Bay, Alaska. PLoS ONE 2015, 10, e0143905. [CrossRef] [PubMed]

22. Parkhurst, D.L.; Appelo, C.A.J. User's Guide to Phreeqc (Version 2): A Computer Program for Speciation, Batch-Reaction, One-Dimensional Transport, and Inverse Geochemical Calculations. Water-Resources Investigations Report 99-4259; 1999. Available online: https://pubs.er.usgs.gov/publication/wri994259 (accessed on 28 June 2020).

23. Lorax Environmental Technical Memorandum: Pebble Project Pit Lake-Water Quality Predictions. To: Loretta Ford, Pebble Limited Partnership. From: Alan Martin, Don Dunbar, Silvano Salvador. 2018. Available online: https://pebbleprojecteis.com/documents/finaleis (accessed on 28 June 2020).

24. Knight Piésold. Pebble Project. Pebble Mine Site-Closure Water Management Plan. Prepared for: Pebble Limited Partnership. 2018. Available online: https://pebbleprojecteis.com/documents/finaleis (accessed on 28 June 2020).

25. SRK Consulting (Canada) Inc. Geochemical Source Terms for Water Treatment Planning, Pebble Project-Operational Phase. Report prepared for Pebble Limited Partnership. SRK Project 1CP016.010. 2018. Available online: https://pebbleprojecteis.com/documents/finaleis (accessed on 28 June 2020).

26. HDR. Pebble Base-Case Water Treatment Plant Engineering Revision. 2018. Available online: https: //pebbleprojecteis.com/documents/finaleis (accessed on 28 June 2020).

27. Knight Piésold. Letter report to Mr. James Fueg, PLP, Re: Pebble Project: RFI 019 Part 4 Influence of Geological Structures on Groundwater Flow Conditions. 2018. Available online: https://pebbleprojecteis. com/documents/finaleis (accessed on 28 June 2020).

28. Golder Associates. Hydrologic Data Report-Water Year 2018. Buckhorn Mine. Submitted to: Crown Resources Corporation; 2019. Available online: https://apps.ecology.wa.gov/paris/DocumentSearch.aspx (accessed on 13 March 2019).

29. Rucker, D.; Glaser, D.R.; Osborne, T.; Maehl, W.C. Electrical Resistivity Characterization of a Reclaimed Gold Mine to Delineate Acid Rock Drainage Pathways. Mine Water Environ. 2009, 28, 146-157. [CrossRef]

30. Gammons, C.H.; Harris, L.N.; Castro, J.M.; Cott, P.A.; Hanna, B.W. Creating Lakes from Open Pit Mines: Processes and Considerations, with Emphasis on Northern Environments; Canadian Technical Report of Fisheries and Aquatic Sciences, 2826; Government of Canada, Fisheries and Oceans Canada: Ottawa, ON, Canada, 2009; p. 106.

31. Plumlee, G.; Logsdon, M.; Filipek, L. The Environmental Geology of Mineral Deposits. Environ. Geochem. Mineral Depos. 1997, 6A, 71-116. [CrossRef]

32. Pebble Limited Partnership (PLP). Pebble Project Supplemental Environmental Baseline Data Report (2004-2012). 11. Geochemical Characterization, Bristol Bay Drainages. 2018. Available online: https: //pebbleprojecteis.com/documents/finaleis (accessed on 28 June 2020).

33. INAP (International Network for Acid Prevention). GARD (Global Acid Rock Drainage Guide. Revised as of 17 December 2018. 2009. Available online: http://www.gardguide.com/index.php?title=Main_Page (accessed on 28 June 2020).

34. Newbrough, P.; Gammons, C.H. An experimental study of water-rock interaction and acid rock drainage in the Butte mining district, Montana. Environ. Geol. 2002, 41, 705-719. [CrossRef] 
35. Nordstrom, D.K. Aqueous Pyrite Oxidation and the Consequent Formation of Secondary Iron Minerals. In SSSA Special Publications; Soil Science Society of America: Madison, WI, USA, 2015; pp. 37-56.

36. Nordstrom, D.K.; Alpers, C.N. Geochemistry of Acid Mine Waters. In The Environmental Geochemistry of Mineral Deposits. Part A: Processes, Techniques and Health Issues; Reviews in Economic Geology, Plumlee, G.S., Logsdon, M.J., Eds.; Society of Economic Geologists: Littleton, CO, USA, 1999; Volume 6A, pp. 133-160.

37. Jambor, J.L.; Nordstrom, D.K.; Alpers, C.N. Metal-sulfate salts from sulfide mineral oxidation. In Sulfate Minerals-Crystallography; Alpers, C.N., Jambor, J.L., Nordstrom, D.K., Eds.; Mineralogical Society of America: Washington, DC, USA, 2000; Volume 40, pp. 303-350.

38. Miller, G.C.; Lyons, W.B.; Davis, A. Peer Reviewed: Understanding the Water Quality of Pit Lakes. Environ. Sci. Technol. 1996, 30, 118A-123A. [CrossRef] [PubMed]

39. Plumlee, G.S.; Smith, K.S.; Montour, M.R.; Ficklin, W.H.; Mosier, E.L. Geologic Controls on the Composition of Natural Waters and Mine Waters Draining Diverse Mineral-Deposit Types. In The Environmental Geochemistry of Mineral Deposits. Part B. Case Studies and Research Topics; Reviews in Economic Geology; Filipek, L.H., Plumlee, G.S., Eds.; Society of Economic Geologists: Littleton, CO, USA, 1999; Volume 6B, pp. 373-432.

40. Albert, D.M. Direct loss of Salmon Streams, Tributaries and Wetlands under the Proposed Pebble Mine Compared with Thresholds of Unacceptable Adverse Effects in the EPA Proposed Determination Pursuant to Section 404(c) of the Clean Water Act; The Nature Conservancy: Arlington, VA, USA, 2019; p. 14. [CrossRef]

41. Nordstrom, D.K. Models, validation, and applied geochemistry: Issues in science, communication, and philosophy. Appl. Geochem. 2012, 27, 1899-1919. [CrossRef]

42. Oreskes, N.; Shrader-Frechette, K.; Belitz, K. Verification, Validation, and Confirmation of Numerical Models in the Earth Sciences. Science 1994, 263, 641-646. [CrossRef] [PubMed]

43. Knight Piésold. Pebble Project Water Balance and Water Quality Model Report. Prepared for Pebble Limited Partnership. Prepared by Knight Piésold Ltd. VA101-176/60-3. 2019. Available online: https: //pebbleprojecteis.com/documents/finaleis (accessed on 27 June 2020).

44. SRK Consulting Inc. Summary of Update to Geochemical Source Terms Originally Issued in August 2018, Pebble Project. SRK Memo to PLP. 2019. Available online: https://pebbleprojecteis.com/documents/finaleis (accessed on 28 June 2020). 